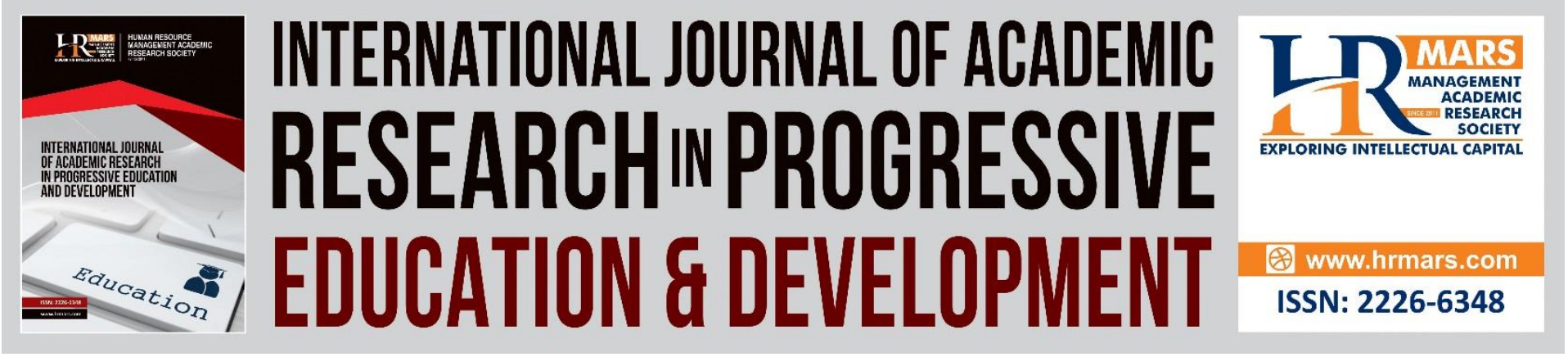

\title{
A Systematic Review on Online Learning Research in Malaysian Higher Education in Post Covid-19 Outbreak: The UITM Researchers Perspectives
}

Ramlan Mustapha, Maziah Mahmud, Norhapizah Mohd Burhan, Lokman Abdul Rasol \& Nur Hidayah Mohamad

To Link this Article: http://dx.doi.org/10.6007/IJARPED/v10-i3/11100 DOI:10.6007/IJARPED/v10-i3/11100

Received: 10 June 2021, Revised: 13 July 2021, Accepted: 28 July 2021

Published Online: 11 August 2021

In-Text Citation: (Mustapha et al., 2021)

To Cite this Article: Mustapha, R., Mahmud, M., Burhan, N. M., Rasol, L. A., \& Mohamad, N. H. (2021). A Systematic Review on Online Learning Research in Malaysian Higher Education in Post Covid-19 Outbreak: The UITM Researchers Perspectives. International Journal of Academic Research in Progressive Education and Development, 10(3), 591-606.

Copyright: (c) 2021 The Author(s)

Published by Human Resource Management Academic Research Society (www.hrmars.com)

This article is published under the Creative Commons Attribution (CC BY 4.0) license. Anyone may reproduce, distribute, translate and create derivative works of this article (for both commercial and non-commercial purposes), subject to full attribution to the original publication and authors. The full terms of this license may be seen at: http://creativecommons.org/licences/by/4.0/legalcode

Vol. 10(3) 2021, Pg. 591 - 606

http://hrmars.com/index.php/pages/detail/IJARPED

JOURNAL HOMEPAGE

Full Terms \& Conditions of access and use can be found at http://hrmars.com/index.php/pages/detail/publication-ethics 


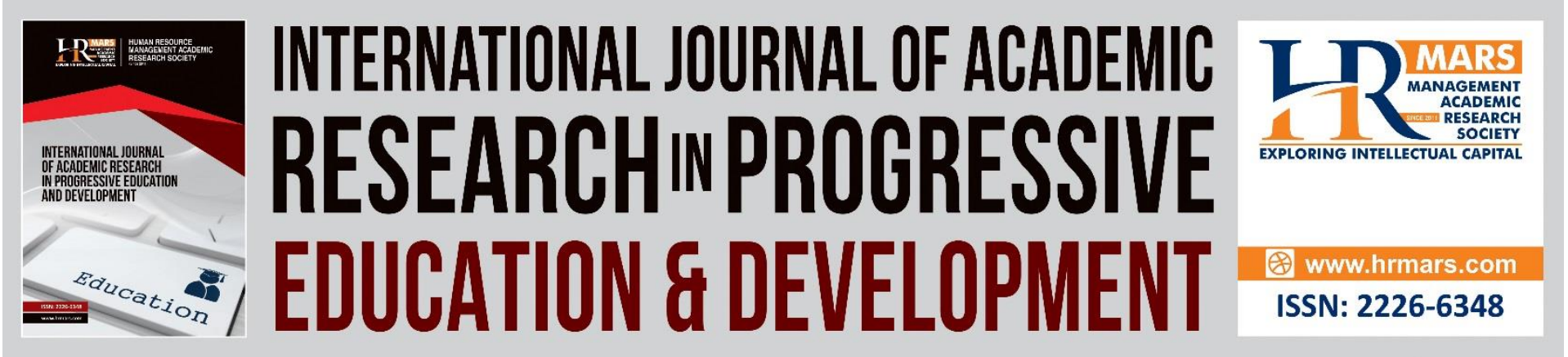

\title{
A Systematic Review on Online Learning Research in Malaysian Higher Education in Post Covid-19 Outbreak: The UITM Researchers Perspectives
}

\author{
${ }^{1}$ Ramlan Mustapha, ${ }^{2}$ Maziah Mahmud, ${ }^{3}$ Norhapizah Mohd \\ Burhan, ${ }^{4}$ Lokman Abdul Rasol \& ${ }^{5}$ Nur Hidayah Mohamad \\ 1,2,3,4Academy of Contemporary Islamic Studies Universiti Teknologi MARA Pahang, Malaysia, \\ ${ }^{5}$ Sekolah Kebangsaan Kedawang, Langkawi Malaysia \\ Email: ramlan@uitm.edu.my
}

\begin{abstract}
This paper reports on a systematic review of 59 pieces of educational research, relating to online learning composed by UITM researcher. Despite the volume of academic literature in this field, researcher found few research studies published in the period 2020-2021 providing findings addressing the review objectives. There was, however, a reasonable weight of research evidence to support the importance of the following factors in online learning such as Student's readiness factor, Open Distance Learning, Student motivation, Stress, Pandemic Covid-19 Challenge, Learning Habit, Learning preparedness, Student's performances, Student's acceptance, Student's satisfaction, Self-regulated learning, and Google classroom/online. The review also found some of the research methods that became the dominant methodology in the study conducted by UITM researchers related to online learning. However, conclusions should be weighed against the limits of the present research. Based on this review of the literature, implications for research and practise, as well as recommendations for next steps, are made.
\end{abstract}

Keyword: Systematic Review, Online Learning, UITM, Covid-19, Higher Education Student.

\section{Introduction}

Corona Virus, commonly known as Covid-19, is a fatal and contagious disease that had a major impact on the global education. This tragedy has also rattled the education sector, and this concern is likely to ripple throughout the education system globally. As a result of the Covid19 pandemic outbreak, several schools and colleges were forced to close for a short period of time. Several locations are affected worldwide, and there is a worry of losing this entire semester or even more in the future. Various institutions, colleges, and universities have stopped in-person (face to face) instruction.

Due to the fact that social distancing is so prevalent at this period, learning possibilities will be negatively affected. Educational institutions are scrambling to come up with solutions to 
this problem. These situations make us recognize that scenario planning for academic institutions is a pressing need (Rieley, 2020; Dhawan, 2020). In spite of the absence of faceto-face schooling, a number of measures are underway to ensure that study activities are carried out. When students and professors are unable to meet in person, they need to adjust and come up with alternate ways, such as implementing online learning.

Online learning has become an increasingly popular technique for credit recovery choices through online courses may assist more students get back on track to graduation (Shimamora, 2020). Meanwhile, the online learning to enhance and increase student learning outcomes while countering the loss in resources, notably in higher education (Nguyen, 2015). Online learning allows students to take a course without having to go to educational institution. Learners have the option of taking a course from the convenience of their own home or office. Learners can also obtain credible certifications, enhancing their qualifications, which are crucial for job advancement (Inchiparamban \& Pingle, 2016).

\section{Online Learning}

Due to rapid technological advancements, distant education has become more convenient (McBrien et al., 2009). Online learning can be described as a technology that can make the teaching-learning process more student-centered, more inventive, and even more adaptable. As defined by the American Psychological Association, online learning is "learning experiences in synchronous or asynchronous environments using different devices (e.g. mobile phones, computers, etc.) with internet connection." As a result of this, students can learn and connect with professors and other students from any location (Singh \& Thurman, 2019). As opposed to asynchronous learning settings, which are not adequately structured, students in synchronous learning environments are required to attend live lectures, engage with educators in real time, and receive instant response from educators. Rather than having live lectures or courses, such a learning environment relies on a variety of learning tools and forums to provide learning information. In such a setting, instant feedback and fast response are impossible (Littlefield, 2018).

Online learning has grown in popularity due to its perceived ability to provide more flexible access to content and instruction by: 1 ) increasing the supply of learning experiences for those who cannot or do not wish to attend traditional schools, 2) assembling and disseminating instructional content more efficiently, and 3) increasing student-instruction time (Shimamora, 2020). As a subset of distance education, online learning has long been concerned with providing access to educational experiences that are, at the very least, more flexible in time and space than campus-based education (Oliver at al., 2009). Therefore, online learning may not be ready to serve all disciplines in the same way, and not all online learning environments are alike. However, the features listed earlier are generic and may be applied to the majority of online learning activities today (Oliver et al., 2009; Scagnoli, 2009; Shimamora, 2020)

\section{Online learning scenario in Malaysia}

The COVID-19 pandemic, as we all know, has had a significant influence on educational institutions around the globe. These issues have caused a temporary disruption in the instructional environment. Education stakeholders are forced to explore for alternative ways to continue the Education programme because of this situation (Mustapha et al., 2021). In this case, Online Learning is a viable solution. Malaysia, in particular, is not immune to this issue. All educational institutions have been instructed by the government to conduct learning 
sessions utilizing a variety of relevant platforms, as long as the learning process is carried out. Based on the technology-based environment, OLL is a viable choice by utilizing multiple platforms such as Webex and other education-friendly platforms such as Google Meet, Zoom, WhatsApp, and Google Classroom.

Malaysia's government is taking steps to boost online education by increasing technological usage among younger generations and providing affordable and realistic education to combat the absence of quality education. Student participation in the online higher education network will continue to rise due to the government's strong initiative (Ullah, Nawi, Shahzad, Khan, \& Aamir, 2017; Mustapha et al., 2021). The Malaysian National e-learning policy in higher education institutions refers to the initiative for building a high quality e-learning system and guidelines for the notion of "One Malaysia" (Model Baru Ekonomi-MBE, Malaysia Ministry of Higher Education, 2011). There are three primary components of electronic learning: LMS, content management systems, and the administration of resources and materials in general. Many ICT specialists are incorporating new tools for on-line learning into the classroom as education technology changes, changing the learning environment. Because of the online networks that connect teachers with students and students with learning resources, Internet technology has an impact on the performance of students and educators. In addition, the Malaysian Ministry of Higher Education plays a significant role in promoting OLL in the learning process, as well. Malaysian higher education institutions are urged to integrate e-learning, or Learning Management Systems (LMS), into their courses and face-toface training, providing a "blended learning" environment for its students (Tayebinik \& Puteh, 2012; Mustapha et al., 2021). Learning Management Systems (LMS) are widely used in higher education institutions for the design, implementation, and management of blended learning models (Martinez \& Jagannathan, 2012). In addition to providing resources for online training, LMSs such as MoOLLe and Blackboard also include tools for student tracking and group work (Pellas \& Kazanidis, 2015). In the meantime, communications, classrooms, efficiency, quality, and administration are the most extensively used LMS features in all Malaysian universities. Nevertheless, just a few colleges have LMS elements that fostered student interaction, such as community and portfolio (Atan, Embi \& Hussin, 2011).

\section{MARA university of Technology Malaysia (UITM)}

MARA University of Technology Malaysia (UiTM) is a Malaysian public university that solely accepts bumiputera students. In 1956, the RIDA (Rural \& Industrial Development Authority) Training Centre (Dewan Latihan RIDA) was formed to help rural Malays, and it opened with roughly 50 pupils. Malaysia's largest higher education institution in terms of physical facilities, faculty, and student enrollment has emerged since then. The institution consists of a main campus and 34 satellite campuses. Over 500 English-taught undergraduate and graduate programmes are available. Around 170,514 full-time and part-time Bumiputera and international students attend the institution.

\section{Research Question}

This article is intended to offer an overview of the current Online Learning (OLL) and related factor which has been done during the covid-19 pandemic by the UITM (Technology University of MARA Malaysia) researcher since 2019 to 2021. This objective also involves the purpose of identifying the theme and factors, including points of detailed theories used, and 
DEVELOPMENT

Vol. 10, No. 3, 2021, E-ISSN: 2226-6348 @ 2021 HRMARS

the type of methodology which is commonly used in their studies. The following research questions have been identified to lead the review:

1. What are the factors and themes used in the study by UITM researchers related to OLL?

2. What is the theory that is the basis of the study of UITM researchers in their study?

3. What kind of research methods are used by UITM researchers in their research?

To answer the above research questions, the 63 published articles from 2019 to 2021 retrieved and extracted from Google Scholar database. From this sample, 44 qualified for review. The process and rations of identifying, screening, eligibility and inclusion of article were discussed in the following section.

\section{Systematic Review Protocol}

This study uses a systematic review approach to explore and preview the study conducted by researchers from UITM (Technology University of MARA, Malaysia) in the field of Online Leraning after the Covid-19 pandemic. A description of the source, research terms, inclusion and exclusion processes and discussion will be described in detail in the following subsections.

\section{Database and Search Terms}

In this study, the researcher only focused on data search using Google Scholar to explore and find the studies that have been done by the researcher from UITM. Google scholar is a database and search engine that is easy and very widely used among researchers instead of Scopus and Web of Sciences database. The study was conducted on 25 June 2021 and is limited to titles, keywords and abstracts. The research procedure for systematic literature review is illustrated in the following sections.

\section{Article Inclusion \& Exclusion Criteria}

Based on the objective of systematic review, to see and explore the current research made by researchers from UITM on Online Distance Learning after the Covid-19 pandemic that began in 2019. The following term and keyword have been used by us to find related articles database from Google Scholar: (“Online Learning") AND ("Malaysia") AND ("Covid-19") AND ("UITM"). In the process of selecting relevant articles, we follow the following inclusion and exclusion criteria process. This study only focuses and limits to 1) journal articles only, 2) articles published from Malaysian researchers only, 3) researchers from UITM only, 4) full text article should be available 5) focus on OLL after the covid-19 pandemic only until now and 6) 2019 to 2021 publication only. 
Table 1: Inclusion criteria for the review

\begin{tabular}{ll}
\hline Criterion type & Inclusion criteria \\
\hline Topic & $\begin{array}{l}\text { The research topic must be related to the research question } \\
\text { (Onliner learning, Covid-19, UITM researcher and Malaysia) } \\
\text { Jecency }\end{array}$ \\
$\begin{array}{l}\text { Journal articles reviewed must be published between 2019 } \\
\text { to } 2021 \text { (because the researcher wanted to focus on the } \\
\text { topic of OLL research during the outbreak of Covid-19) }\end{array}$ \\
Research base & $\begin{array}{l}\text { Literature must be based on empirical research } \\
\text { (quantitative, qualitative, mixed method or development } \\
\text { research) } \\
\text { Reliability/validity } \\
\text { The sample }\end{array}$ \\
$\begin{array}{l}\text { The finding upon which the literature reviewed must be } \\
\text { valid and reliable to the context of study } \\
\text { The literature reviewed must be a study made by a } \\
\text { researcher from University Teknologi MARA Malaysia } \\
\text { (UITM) only. If the relevant literature from the researcher } \\
\text { is otherwise, it will be excluded. }\end{array}$ \\
\hline
\end{tabular}

\section{Search Result}

By using the search process using Boolean Operator and inclusion criteria, a total of 63 peer reviewed articles were retrieved. Then we made a selection process for articles related to "inclusion" with the objectives of the study. We went to two steps to include relevant studies to meet the objectives of this study. First, we excluded documents that were less relevant to the objectives of the study by looking at the title of the study, the abstract of the study and the focus of the researcher who made the study. Second, we screened the full text and we excluded 8 irrelevant articles and 51 remained. Then we narrow it down to articles published in 2019 to 2021 only, 7 article excluded and the result is only 44 related articles remaining. Then the screening and selection as in the following diagram: 

DEVELOPMENT

Vol. 10, No. 3, 2021, E-ISSN: 2226-6348 @ 2021 HRMARS

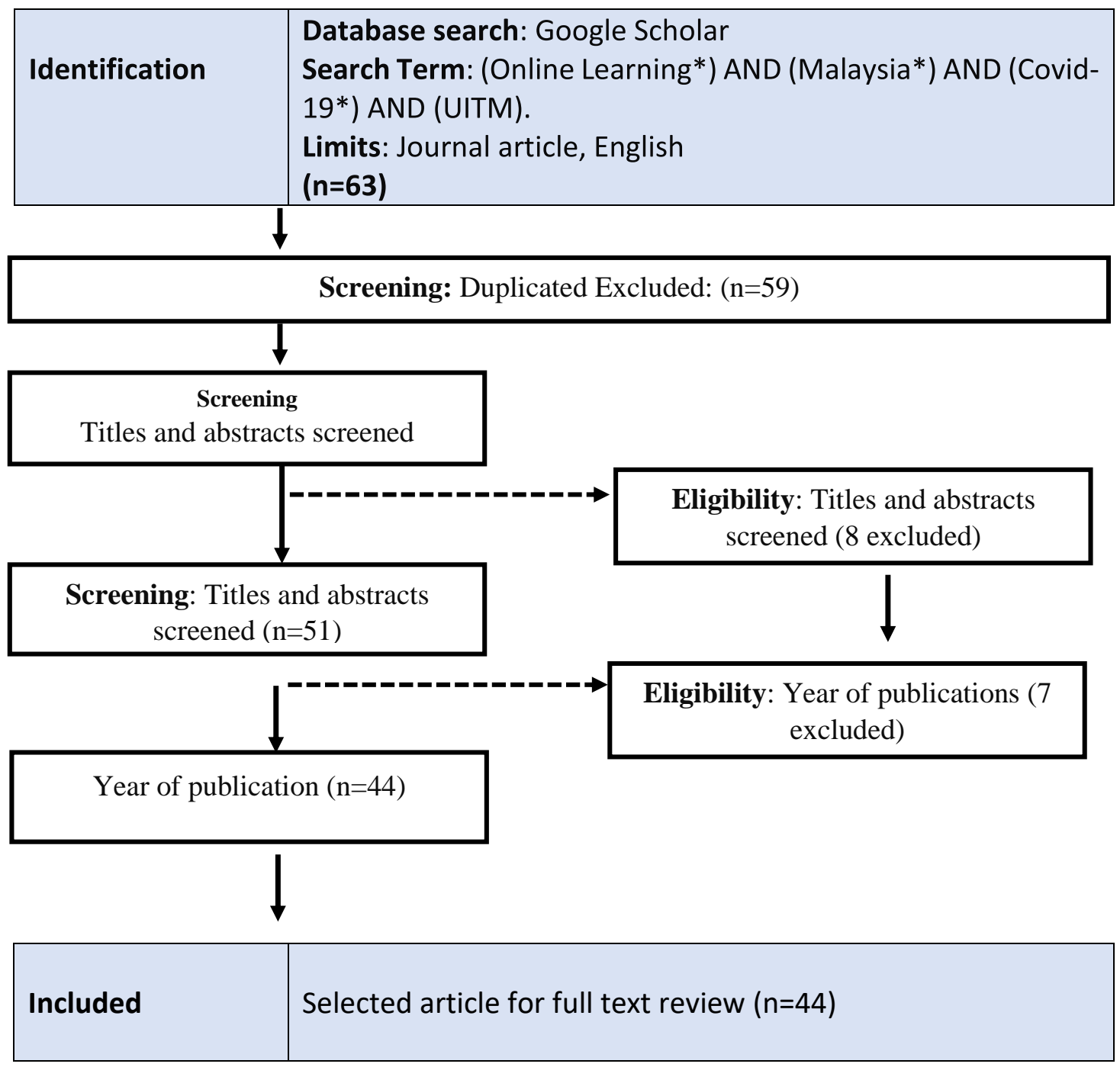

Figure 1: Flow diagram of the article search and Selection process

\section{Result}

\section{Theme and factors}

Table 2 shows the distribution of the main themes and factors that are the topic of discussion among UITM researchers regarding OLL. 
Table 2: Main Theme and factor discussed

\begin{tabular}{llll}
\hline Factors/theme & $\begin{array}{l}\text { Numbers } \\
\text { of article }\end{array}$ & percentage & Sources of sample factors \\
\hline Students & 6 & $13 \%$ & Chung, Subramaniam, \& Dass (2020),
\end{tabular}

readiness factor

Open Distance $22 \quad 50 \%$ Learning

\section{Student motivation}

Stress

Online Learning 23 Chung, Noor, \& Mathew, V. N. (2020), Anwar, Omar, Isa, \& Shamsudin, (2020), Mazlan, Ismail Norwahi, \& Zolkapli. (2020), Aminuddin Mohd Azmi, Sulaiman, \& Saini (2021), Hamzah, Phong, Sharifudin, Zain \& Rahim, M. (2021), Jumal et al. (2021). Yacob et al. (2020), Mathew \& Chung (2020), Adnan et al. (2021), Wan Abdul Aziz et al. (2020), Musa et al. (2020), Kheng, Suffarruddin, \& Khamis, (2020), Azmi \& See May (2021), Allamet al. (2020), Wan Chik et al, (2021), Abd Rahman (2020), Muin, (2021), Radzi\& Sulaiman (2021), Lian, \& Ru, (2020), Yahya \& Yusof (2021), Mohamad,

Hashim, Azer\& Che (2020), Rahim, Daud, Kadir \& Jamil (2020), Mustapha et al. (2021), Yahya, Said, \& Yusof. (2021), Deraman et al. (2021), Mydin, et al (2020), Hashim et al, (2020), Azmi et al.(2021), Mahdi et al.(2020),

Ibrahim et al.(2020), Abdul Hafidz et al.(2021), Wahab et al.(2021), Mahmud et al.(2020),

Ahmadon et al.(2020), Yacob et al.(2020), Chung et al.(2020), Ramli et al.(2020), Bahar, Wahab \& Ahmad (2020), ASafri et al. (2020), Omar et al.(2020), Mydin et al.(2020), Abd Azizi et al.(2021), Foong,Ismail\& Tukiman. (2021), Rahman (2020), Abd Aziz, Musa, Malik, Khalid \& Mkom (2020), Anis et al.(2020), Iliias et al.(2020), Sim et al (2021), Abd Malik (2021), Abdullah, Rahmat \& zawawi,(2020), Ahmad (2020), Deraman et al.(2021), Jumal et al.(2021), Soo et al.(2021), Azhar, 


\begin{tabular}{|c|c|c|c|}
\hline $\begin{array}{l}\text { Pandemic Covid- } \\
19 \text { Challenge }\end{array}$ & 2 & $4 \%$ & $\begin{array}{l}\text { Musa et.al (2020), Wan Abd Aziz et.al } \\
\text { (2020) }\end{array}$ \\
\hline Learning Habit & 1 & $2 \%$ & $\begin{array}{l}\text { Ghazali, Zain, Fesol, Mansor, Suffian, } \\
\text { \& Ghazali, (2020). }\end{array}$ \\
\hline $\begin{array}{l}\text { Learning } \\
\text { preparedness }\end{array}$ & 1 & $2 \%$ & $\begin{array}{l}\text { Adnan, Wahid, Ujang, Yacob, \& Zaini, } \\
\text { (2021 }\end{array}$ \\
\hline $\begin{array}{l}\text { Students } \\
\text { performances }\end{array}$ & 1 & $2 \%$ & Azmi, \& See May, (2021). \\
\hline $\begin{array}{l}\text { Students } \\
\text { acceptance }\end{array}$ & 4 & $9 \%$ & $\begin{array}{l}\text { Anwar, Omar, Isa, \& Shamsudin. } \\
\text { (2020), Lian, \& Ru, (2020), Abd Aziz et } \\
\text { al. (2021), }\end{array}$ \\
\hline $\begin{array}{l}\text { Students } \\
\text { satisfaction }\end{array}$ & 2 & $4 \%$ & $\begin{array}{l}\text { Chung \& Mathew (2020). Mohamad, } \\
\text { Hashim, Azer, \& Che, (2020), }\end{array}$ \\
\hline $\begin{array}{l}\text { Self-regulated } \\
\text { learning }\end{array}$ & 1 & $2 \%$ & Yahya (2021) \\
\hline $\begin{array}{l}\text { Google } \\
\text { classroom/online }\end{array}$ & 2 & $4 \%$ & $\begin{array}{l}\text { Leng, Sheng, Yeap, \& (2021), Yusoff, \& } \\
\text { Kadar, (2020). }\end{array}$ \\
\hline
\end{tabular}

Jamaludin \& Daud (2021), Wahid et al.(2021), Mustapha et.al.(2021)

Based on table 2, we summarize the titles and themes of the study conducted by UITM researchers related to OLL during the Covid-19 pandemic between 2019 to 2021 to the following summary. we identified the majority of studies conducted by UITM academic lecturers related to Online learning which represents as much as (52\%), followed by Online Distance learning (50\%), Students readiness factors (13\%), student stress (9\%), Student acceptance of OLL (9\%), Students motivation (4\%), Pandemic Covid-19 challenge (4\%), Student satisfaction of OLL (4\%), Google classroom (4\%), Learning habit (2\%), self-regulated $(2 \%)$, learning preparedness (2\%) and students performances $(2 \%)$.

\section{Types of Research Methods}

Table 3. Research method

\begin{tabular}{llll}
\hline & & $\begin{array}{l}\text { Number of research } \\
\text { published }\end{array}$ & $\begin{array}{l}\text { Number of article } \\
\text { (percentage) }\end{array}$ \\
\hline \multirow{3}{*}{ Type of research } & Quantitative & 32 & $72 \%$ \\
/study & Qualitative & 7 & $15 \%$ \\
& Mixed method & 3 & $8 \%$ \\
& Development Research & 2 & $5 \%$ \\
\hline
\end{tabular}

Table 3 shows a summary of methods used by UITM researchers in their study. Most research methodologies used in their study are quantitative $(72 \%)$, followed by qualitative method $(15 \%)$, then mixed method (8\%) and development research that is $(5 \%)$. 
DEVELOPMENT

Vol. 10, No. 3, 2021, E-ISSN: 2226-6348 @ 2021 HRMARS

\section{Theoretical Perspectives}

Table 4: theoretical perspectives

\begin{tabular}{ll}
\hline Theories & Numbers of article \\
\hline Learning theories & $1(2 \%)$ \\
Theory of Reason Action & $1(2 \%)$ \\
Theory of planned behavior & $2(5 \%)$ \\
Technology Acceptance Model (TAM) & $3(7 \%)$ \\
& $1(2 \%)$ \\
Motivational model & $1(2 \%)$ \\
Diffusion of innovation theory & $1(2 \%)$ \\
Unified Theory of Acceptance and Use of & \\
Technology & $34(77 \%)$ \\
Not mentioned &
\end{tabular}

Considering the theories applied in the studies, the theory of study was not mentioned is $34 \%$ of reviewed studies. The Technology Acceptance Model (TAM) is the prominent theory used by UITM researcher in their research (7\%), followed by Theory of Planned Behavior (5\%). However, some theories (Learning Theories, Theory of Reasoned Action, and Motivational Theory, Diffusion of Innovation Theory and Unified Theory of Acceptance and Use of Technology) were only used by a single study.

\section{Publication Years}

Table 5: Evaluation of numbers of article over time (2019-2021)

\begin{tabular}{lll}
\hline Years & Number of publications & percentage \\
\hline 2019 & 0 & 0 \\
2020 & 29 & $65 \%$ \\
2021 & 15 & $35 \%$ \\
\hline
\end{tabular}

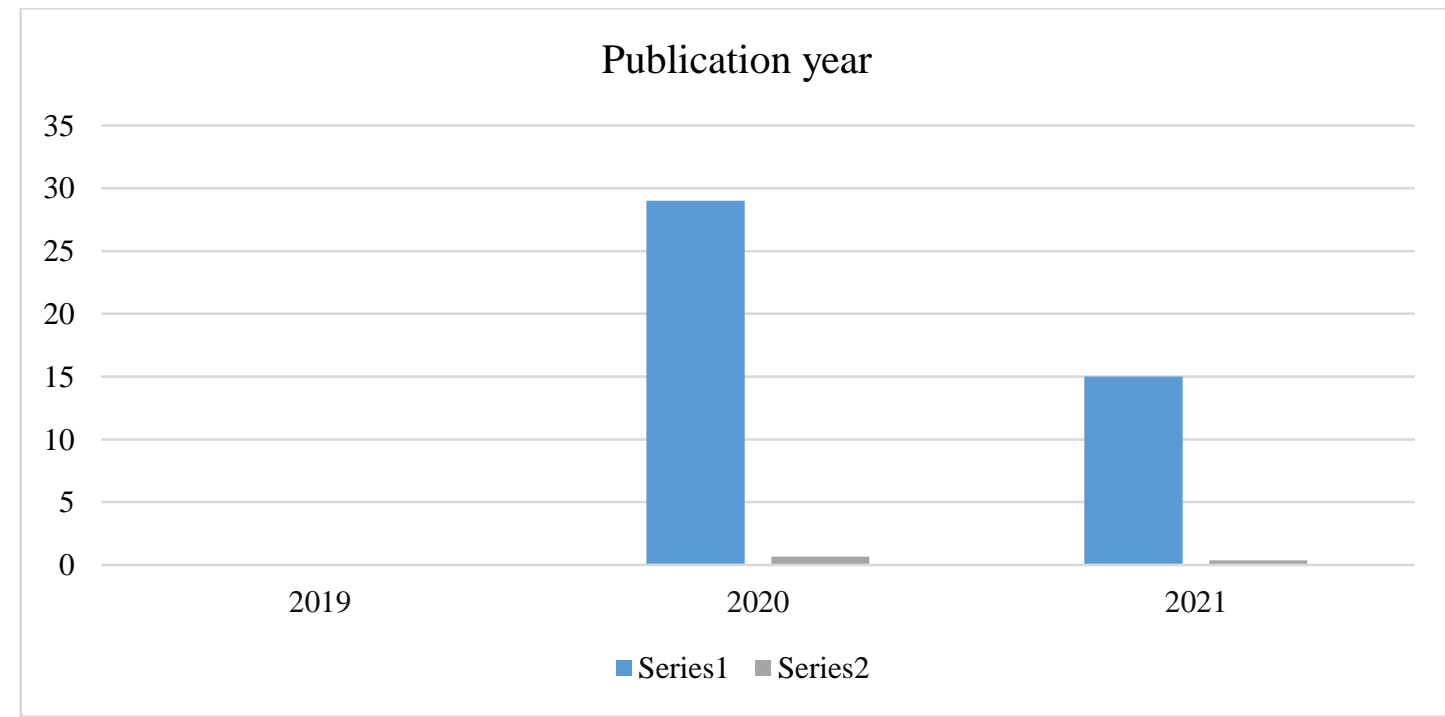

Figure 2. Evaluation of numbers of article over time (2019-2021)

Based on table 5 and diagram 2, we illustrate the distribution of publications based on the year starting in 2019 which is the beginning of the Covid-19 pandemic. We assumed that there 
were researchers from uitm who were doing research related to Covid 19 and Online distance learning at that time. As a result of the data analysis conducted, no studies related to OLL/OLL were made in 2019 when the Covid-19 pandemic occurred. However, in 2020 there were 29 (65\%) related studies from UITM researchers and a total of 15 (35\%) related studies in 2021.

\section{Discussion: Research Gaps, Contribution and Future Research Directions}

The results of the analysis of studies made by UITM researchers related to OLL during the covid-19 pandemic, we generate and summarize the research gaps and future research direction on OLL and related matters for the attention of future researchers as follow:

This study specifically focuses on researchers from UITM Malaysia. As UITM is the largest university in Malaysia with almost 27 branches throughout Malaysia. We assumed at an early stage that, with the large number of researchers, then the studies related to OLL from UITM researchers were numerous. Based on constraints and pandemics, it is very likely that the researcher will not be able to conduct the study effectively. In the future, UITM researchers must move fast with high-impact studies in line with its status as the largest university in Malaysia.

The quantitative method seems to be the favorite research method among UITM researcher. As the results of the analysis show almost $72 \%$ of the studies were conducted using quantitative method. Since the quantitative method is used to test the factors that happen to something, then it is very good if UITM researchers explore in more depth in order to dig into the problem in more detail and depth. Future researchers can use qualitative research to explore a study in more depth.

Most of the studies we have reviewed only a handful of researchers use theory in their studies. As we know that Theory is the most important aspect in determining the direction of the study. Based on table 4, of the 44 studies reviewed, 34 studies did not mention the theory used as the basis of the study. Only a few theories are used, and many are TAM theories involving only 3 studies and followed by TPB of 2 studies. The rest of the theories noted that only one was used in the study. Future researchers can use certain theories in their research, by expanding the theories, testing the theories, and combining the existing theories to make the study more meaningful.

From the observational point of view of researchers, this study contributed significantly to the context of the study. In this era of pandemics, most classes and lectures are conducted online. The need for knowledge and skills on online learning is very important to be carefully studied. Studies like this can analyze problems and suggest methods of implementation or improvement that can be used in classrooms or lectures. Based on the information obtained in this systematic literature review, we can see the gap that still exists in online learning-based studies. There is still a shortage of materials implemented in the context of UITM and this online learning study. The information obtained from this study may be a guide and criteria that future researchers may consider in a more stimulating study in this area.

Finally, we suggest a few things as a guide for future studies. Future studies can use qualitative research in exploring and identifying the potential issues faced while conducting OLL during the Covid-19 pandemic. In addition, we see some things that can be emphasized in future studies such as, study on emotional aspects of students, external pressures such as internet coverage, gadgets, online platforms, platform references that student really need in undergoing the OLL process. These external factors, become the trigger to the success or failure of OLL. Therefore, specific studies on this aspect need to be improved and studied. 


\section{References}

Anwar, I. S. K., Omar, N., Isa, N. S. M., \& Shamsudin, S. M. (2020). STUDENTS'ACCEPTANCE AND READINESS TOWARDS DISTANCE LEARNING DURING COVID-19 PANDEMIC. International Journal of Education and Pedagogy, 2(4), 39-50.

Abdullah, N. A. A., Rahmat, N. H., \& Zawawi, F. Z. (2020). Interactional Discourse Analysis Of Malaysian And South Korean Newspaper Articles On Online Learning During COVID19. European Journal of Applied Linguistics Studies, 3(1).

Anis, S. N. M., Ibrahim, M. A., Tahir, L. M., Abu, B., Khan, A., \& Aziz, R. A. (2020). COVID 19 and campus experience: Survey on online learning and time spent during the movement control order (MCO) among Malaysian postgraduates. Journal of Advanced Research in Dynamical and Control Systems, 12 (7 Spec), 2929-2933.

Abd Rahman, N. H. (2020). THE IMPACTS OF OLL DURING MCO@ COVID-19. Creative and Innovative Teaching Practices during Covid-19 Movement Control Order (MCO), 1, 4450.

Abdul Hafidz, Q. S., Noorshahlin, N. F. N., Remy Khairil, N. F., \& Akmar, H. N. N. (2021). Stress among students during MCO. E-Journal of Media and Society (e-JOMS), 6.

Abd Aziz, N. A., Musa, M. H., Khalid, R. M., Abd Aziz, N. N., \& Malik, S. A. (2021). The Acceptance of E-Learning among Distance Learners: A case study on public universities in South Malaysia. Environment-Behaviour Proceedings Journal, 6(16), 61-67.

Abd Aziz, N. A., Abd Aziz, N. N., Musa, M. H., Malik, S. A., Khalid, R. M., \& MKom, N. N. S. (2020). Exploring Barriers Contributing towards an Effective Online Learning among Undergraduates' Students using PLS-SEM. Environment-Behaviour Proceedings Journal, 5(15), 71-76.

Ahmadon, F., Ghazalli, H. I. M., \& Rusli, H. M. (2020, December). Studying during Pandemic: A Review of Issues from Online Learning in the Middle of COVID-19. In 2020 6th International Conference on Interactive Digital Media (ICIDM) (pp. 1-4). IEEE.

Ahmad, J. H. (2021). Satisfaction with online learning among MDAB students at UiTM Kelantan transition from high school to university/Siti Dalina Tumiran@ Kamal Nasser and Junaidah Hanim Ahmad.

Adnan, N. I. M., Wahid, S. N. S., Ujang, S., Yacob, N. A., \& Zaini, A. A. (2021, May). Open and distance learning preparedness factors among academicians in UiTM (Pahang) using logistic regression. In AIP Conference Proceedings (Vol. 2355, No. 1, p. 060005). AIP Publishing LLC.

Aminuddin, A. S., Mohd Azmi, N. F., Sulaiman, M. A., \& Saini, N. A. (2021). Readiness for online distance learning (OLL) understanding the attitudes among students in UiTM Pahang. Proceedings of International Conference on Language, Education, Humanities \&Social Sciences (i-LEdHS2021), 22 Febuari 2021

Anwar, I. S. K., Omar, N., Isa, N. S. M., \& Shamsudin, S. M. (2020). STUDENTS'ACCEPTANCE AND READINESS TOWARDS DISTANCE LEARNING DURING COVID-19 PANDEMIC. International Journal of Education and Pedagogy, 2(4), 39-50.

Allam, S. N. S., Hassan, M. S., Sultan, R., Mohideen, A. F. R., \& Kamal, R. M. (2020). Online Distance Learning Readiness during Covid-19 Outbreak among Undergraduate Students. Journal of Academic Research in Business and Social Sciences, 10(5), 642-657.

Atan, H., Embi, M. A., \& Hussin, S. (2011). E-Learning Policy in Malaysian Higher Education Institutions. In e-Learning in Malaysian Higher Education Institutions: Status, Trends, \& Challenges 
Azmi, A. S., \& See May, L. (2021). The impact of Online Leraning(OLL) on students' performance in Universiti Teknologi MARA Kelantan branch.

Azhar, N. H., Jamaluddin, M. F., \& Daud, D. (2021). Effectiveness of online learning during pandemic of Covid-19 among educators in higher learning institutions: an overview/Noor Hidayah, Mohd Farizi and Dazmin Daud. Journal of Media and Information Warfare (JMIW), 14, 21-29.

Bahar, N., Wahab, S. N., \& Ahmad, N. D. (2020, December). Understanding Challenges Faced in Online Teaching and Learning Among Malaysian Universities' Instructors During COVID-19 Pandemic. In 2020 Sixth International Conference on e-Learning (econf) (pp. 154-157). IEEE.

Chung, E., Subramaniam, G., \& Dass, L. C. (2020). Online Learning Readiness among University Students in Malaysia amidst COVID-19. Asian Journal of University Education, 16(2), 4658.

Chung, E., Noor, N. M., \& Mathew, V. N. (2020). Are you ready? An assessment of online learning readiness among university students. International Journal of Academic Research in Progressive Education and Development, 9(1), 301-317.

Chung, E., \& Mathew, V. N. (2020). Satisfied with online learning amidst COVID-19, but do you intend to continue using it. International Journal of Academic Research in Progressive Education and Development, 9(4), 67-77.

Deraman, N. A., Buja, A. G., Wahid, S. D. M., \& Isa, M. A. M. (2021). Mining social media opinion on online distance learning issues during and after movement control order (MCO) in Malaysia using topic modeling approach. International Journal of Advanced Technology and Engineering Exploration, 8(75), 371.

Dhawan, S. (2020). Online learning: A panacea in the time of COVID-19 crisis. Journal of Educational Technology Systems, 49(1), 5-22.

Foong, N. S., Ismail, A., \& Tukiman, N. (2021). Students' Perception on Using Teaching Video in Online Learning During COVID-19 Pandemic. Journal of Creative Practices in Language Learning and Teaching (CPLT), 9(1).

Ghazali, N., Zain, N. H. M., Fesol, S. F. A., Mansor, M., Suffian, M., \& Ghazali, N. H. (2020). Undergraduates' learning habits amid covid-19 pandemic: A pilot study. Journal of Advanced Research in Dynamical and Control Systems, 12(7), 1251-1260.

Hamzah, F., Phong, S. Y., Sharifudin, M. A. S., Zain, Z. M., \& Rahim, M. (2021). Exploring Students' Readiness on English Language Blended Learning. Asian Journal of University Education, 16(4), 161-170.

Hashim, H., Kadir, N. A. A., Mansor, F., \& Azudin, M. Z. M. (2020). Open and Distance Learning (OLL) During Movement Control Order (MCO): Conceptualising the Relationships between Self-Efficacy. Learning Motivation and Performance of Higher Learning Education Students. International Journal of Academic Research in Business and Social Sciences, 10(8), 258-269.

Ibrahim, W. N. A. I., \& Rosdi, N. A. M. (2020). Stress Level among UiTM Puncak Alam Students during the Movement Control Order. Environment-Behaviour Proceedings Journal, 5(15), 109-115.

Inchiparamban, S., \& Pingle, S. (2016). Massive open online courses (MOOCs): Why do we need them?(ED590312). ERIC.http://files.eric.ed.gov/fulltext/ED590312.pd 
Ilias, A., Baidi, N., Ghani, E. K., \& Razali, F. M. (2020). Issues on the use of online learning: An exploratory study among university students during the COVID-19 pandemic. Universal Journal of Educational Research, 8(11), 5092-5105.

Kheng, L. K., Suffarruddin, S. H., \& bin Khamis, M. S (2020). The effectiveness of oll method for ent530 during the pandemic of covid-19. Fbm insights, 65.

Lian, T. Y., \& Ru, C. J. (2020). A study on the perception and acceptance of UiTM's undergraduates towards open and distance learning method in Mandarin language teaching and learning during covid-19 movement control order period. International Journal of Modern Languages and Applied Linguistics (IJMAL), 4(4), 61-79.

Littlefield, J. (2018). The difference between synchronous and asynchronous distance learning. https://www.thoughtco.com/synchronous-distance-learning-asynchronousdistancelearning-1097959

Leng, C. O., Sheng, C. Y., Yeap, C. K., \& Tan, C. P. (2021). Students'perceptions Towards Using Google Slides and Google Classroom as Online Collaborative Tools in Mandarin Learning. Journal of Islamic, 6(36), 89-99.

Mazlan, N. A., Ismail, W. M. W., Norwahi, N. A., \& Zolkapli, N. M. (2020). The Effect of Student Readiness on Student Understanding During OLL Sessions in UiTM Melaka. International Journal of Academic Research in Progressive Education and Development, Vol. 9(2) 2020, Pg. $713-721$

Mahdi, A. F., Lajim, S. F., Shamsuddin, N. E., \& Kanyan, A. (2020). Effect of E-Learning towards University Students Motivation. Borneo International Journal eISSN 2636-9826, 3(1), 813.

Martinez, M., \& Jagannathan, S. (2012). Learning solution: MoOLLe: A low-cost solution for successful e-learning.Retrieved from

http://www.learningsolutionsmag.com/articles/71/moOLLealow-cost-solution-forsuccessful-e-learning

McBrien, J. L., Cheng, R., \& Jones, P. (2009). Virtual spaces: Employing a synchronous online classroom to facilitate student engagement in online learning. The International Review of Research in Open and Distributed Learning, 10(3), 1-17

Mohamad, S. A., Hashim, H., Azer, I., \& Che, H. (2020). Gender Differences in Students' Satisfaction and Intention to the Continuation of Online Distance Learning. International Journal of Academic Research in Business and Social Sciences, 10(9), 641-650.

Mahmud, Z., Rahim, R. A., Abidin, A. W., \& Abdullah, N. N. N. (2020). Mental and Emotional Wellbeing during the COVID-19 Pandemic: The Unprecedented Malaysian Experience. Current Psychiatry Research and Reviews Formerly: Current Psychiatry Reviews, 16(4), 244-256.

Mathew, V. N., \& Chung, E. (2020). University Students' Perspectives on Open and Distance Learning (OLL) Implementation amidst COVID-19. Asian Journal of University Education, 16(4), 152-160.

Ministry of Higher Education Malaysia. (2011). "Dasar E-Pembelajaran Negara Institusi Pengajian Tinggi," 2011.

Musa, A. H., Rosle, A. N., Baharuddin, F. N., \& Sara, S. (2020). The Effectiveness of Online Distance Learning (OLL) Approach in University: A Respond of Covid-19 Pandemic Crisis. Journal of Academic Research in Business and Social Sciences, 10(9), 1069-1076. 
Musa, A. H., Rosle, A. N., Baharuddin, F. N., \& Ibrahim, S. S. (2020). CHALLENGES IN ONLINE DISTANCE LEARNING (OLL) DELIVERY DURING COVID-19 PANDEMIC CRISIS. THE INTERDISCIPLINARY OF MANAGEMENT, ECONOMIC AND SOCIAL RESEARCH, 6.

Mustapha, R. (2021). Development of E-Xtvt Guidelines in Promoting Active Online Learning In Higher Education: The Fuzzy Delphi Approach. Psychology and Education Journal, 58(1), 5681-5696.

Muin, N. A. (2021). Supporting and engaging isolated language learners in open and distance learning (oll) classes: a comparative study between a malaysian and an indonesian university undergraduate students. In e-proceedings (p. 410).

Mydin, A. M., Mohammad, W. A. W., \& Kechil, R. (2020). Online Distance Learning and Online Learning Implementation To Civil Engineering Student For Subject CSC128. Volume 1, September 2020, 113.

Nguyen, T. (2015). The Effectiveness of Online Learning: Beyond No Significant Difference and Future Horizons. MERLOT Journal of Online Learning and Teaching, 11(2), 309-319

Omar, N., Isa, N. S. M., Rahman, L. A., \& Fatzel, F. H. M. (2020). FACTORS INFLUENCING STUDENTS'ACCEPTANCE OF E-LEARNING: A CASE STUDY OF UITM TAPAH ACCOUNTING STUDENTS. International Journal of Education and Pedagogy, 2(4), 1-15.

Oliver, R., Tallent-Runnels, M. K., Thomas, J. A., Lan, W. Y., Cooper, S., Ahern, T. C., Shaw, S. M., Liu, X., Bolliger, D. U., Wasilik, O., Henry, P., Nakayama, M., Mutsuura, K., Yamamoto, H., Sadeck, O., Cronjé, J., Williams, H. N., Redmond, P., Abawi, L. A., ... Mcisaac, M. (2009). The theory and practice of online learning: Towards a theory of online learning. Electronic Journal of E-Learning, 38(4), 93-135.

Pellas, N., \& Kazanidis, I. (2015). On the value of Second Life for students' engagement in blended and online courses: A comparative study from the Higher Education in Greece. Education and Information Technologies. https://doi.org/10.1007/s10639-013-9294-4

Radzi, M. Q. A. N. A., \& Sulaiman, S. (2021). Online Distance Learning New Norm in Undergraduate Graphic Design Education. Idealogy Journal of Arts and Social Science, 6(1), 43-48.

Rahim, E. E. A., Daud, N., Kadir, S. A. A., \& Jamil, N. W. (2020). Students' perceptions of Open and Distance Learning (OLL) for theoretical and lab-related subjects. In 2020 IEEE Conference on e-Learning, e-Management and e-Services (IC3e) (pp. 29-32). IEEE.

Rahman, M. S. A. (2020). TEACHING AND LEARNING CALCULUS THROUGH VIDEO CONFERENCE DURING THE COVID-19 PANDEMIC: GOOGLE MEET. Volume 1, September $2020,88$.

Saidi, R. M., Sharip, A. A., Abd Rahim, N. Z., Zulkifli, Z. A., \& Zain, S. M. M. (2021). Evaluating Students' Preferences of Open and Distance Learning (OLL) Tools. Procedia Computer Science, 179, 955-961.

Safri, S. N. W., Mohi, Z., \& Hanafiah, M. H. (2020). Massive Open Online Course (MOOC): Our saviour during COVID-19 pandemic?. Journal of Tourism, Hospitality \& Culinary Arts (JTHCA) 2020, Vol. 12 (3) pp 120-128

Scagnoli, N. (2009). A review of online learningand its evolution in Latin America. Policy Futures in Education, 7(5), 555-565.https://doi.org/10.2304/pfie.2009.7.5.555

Simamora, R. M. (2020). The Challenges of online learning during the COVID-19 pandemic: An essay analysis of performing arts education students. Studies in Learning and Teaching, 1(2), 86-103. 
Singh, V., \& Thurman, A. (2019). How many ways can we define online learning? A systematic literature review of definitions of online learning (1988-2018). American Journal of Distance Education, 33(4), 289-306

Soo, K. Y., Hasan, N. H., Syed Ahmad, T. S. A., Ismail, N., Zainon, S., \& Abdullah, M. (2021). Exploring the design of online content for e-learning/Soo Kum Yoke.

Tayebinik, M., \& Puteh, M. (2012). Blended Learning or E-learning? International Magazine on Advances in Computer Science and Telecommunications, 3(1), 103-110

Ullah, A., Nawi, M. N., Shahzad, A., Khan, S. N., \& Aamir, M. (2017). An E-learning System in Malaysia based on Green Computing and Energy Level. JOIV: International Journal on Informatics Visualization. https://doi.org/10.30630/joiv.1.4-2.63

Wahab, M. Z. H., \& Othman, K. (2021). Impact of COVID-19 on Student's Emotional and Financial Aspects in the Higher Learning Institutions. SEISENSE Journal of Management, 4(4), 1-15.

Wahid, H. S. A., Rahmat, N. H., Dzuradeen, N. S., \& Kadir, N. A. (2020). ARE STUDENTS ENGAGING IN ONLINE CLASSROOMS? European Journal of Education Studies, 7(12).

M Yacob, N. H., Mohammad Fadzillah, N. S., Wan Abdul Rahman, N. H., Mustafa, L. M., Jamaluddin, S., \& Bahari, M. A. B. (2020). Learning experience and barriers throughout Online Leraningmode: A case study of UiTM Pahang students. Gading Journal for Social Sciences, 23(2), 25-33.

Yahya, N. A., Said, J. M., \& Yusof, A. M. (2021). Students' self-regulated learning in open and distance learning for Mathematics course. EDUCATUM Journal of Science, Mathematics and Technology, 8(1), 1-5.

Yusoff, S. A. M., \& Kadar, R. (2020). IMPLEMENTING GOOGLE ONLINE AND KAMI APPLICATIONS TO SUPERVISE ONLINE DISTANCE TEACHING AND LEARNING (OLL). Volume 1, September 2020, 76. 